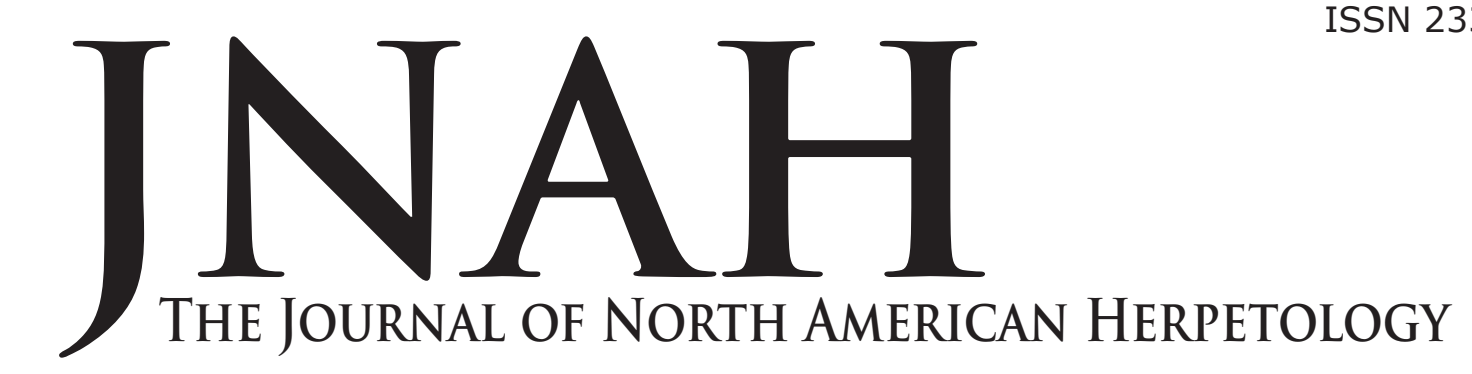

Volume 2014(1): 81-86 2 July 2014 jnah.cnah.org

\title{
DISTRIBUTION, DIET, AND PREVALENCE OF AMPHIBIAN CHYTRID FUNGUS IN NON-NATIVE AMERICAN BULLFROGS (LITHOBATES CATESBEIANUS) AT THE VALENTINE NATIONAL WILDLIFE REFUGE, NEBRASKA, USA
}

\author{
ALYX R. LINGENFELTER ${ }^{1}$, KEITH GELUSO ${ }^{1,4}$, MELVIN P. NENNEMAN ${ }^{2}$, \\ BRIAN C. PETERSON ${ }^{1}$ AND JACOB L. KERBY ${ }^{3}$
}

\begin{abstract}
${ }^{1}$ Department of Biology, University of Nebraska at Kearney, Kearney, Nebraska 68849
${ }^{2}$ Valentine National Wildlife Refuge, 39679 Pony Lake Road, Valentine, Nebraska 69201

${ }^{3}$ Department of Biology, University of South Dakota, Vermillion, South Dakota 57069

${ }^{4}$ Corresponding author: gelusok1@unk.edu
\end{abstract}

\begin{abstract}
American Bullfrogs (Lithobates catesbeianus) have been widely introduced beyond their native range in North America and can negatively affect organisms in wetland environments via a suite of mechanisms including interspecific interactions and disease transmission. Bullfrogs were introduced to the Valentine National Wildlife Refuge in the Sandhill Region of Nebraska, USA, yet little is known regarding their distribution, abundance, and potential effects on other vertebrates in the Refuge. Surveys in 1991-1992 documented bullfrogs in only one lake by the Refuge headquarters, and anecdotal historical observations indicated that bullfrogs were present primarily in lakes open to public fishing. In 2012, we determined the distribution of bullfrogs across the Refuge, examined their diets, and sampled them for the occurrence of the pathogenic fungus, Batrachochytrium dendrobatidis. We documented that bullfrogs were almost ubiquitous across the Refuge lakes and wetlands. From diet analyses, we observed that adult bullfrogs consumed several vertebrate species on the Refuge including: a Blanding's Turtle (Emydoidea blandingii), small bullfrogs, an unidentifiable frog species, and numerous invertebrates, including crayfish. The amphibian chytrid fungus was prevalent on the refuge with $73.7 \%$ of bullfrogs testing positive for the fungus in early June and $6.3 \%$ in late June-July. Preliminary data indicate that bullfrogs likely have already affected interspecific interactions with native amphibians via predation, competition, and/or disease transmission. Bullfrogs likely cannot be eradicated from the Refuge, but expanding the season of harvest of bullfrogs might reduce their abundance, which may benefit native amphibians and reptiles.
\end{abstract}

\section{INTRODUCTION}

American Bullfrogs (Lithobates catesbeianus; hereafter, bullfrogs) originally were native to southern and eastern North America, but the species has been widely introduced throughout western and northern parts of the United States (Bury and Whelan, 1984; Ficetola et al., 2007). The exact western limits of its native distribution are not well understood across the Great Plains. In Nebraska, for example, bullfrogs are suspected to be native only to eastern parts of the state in river-bottoms and river oxbows (McAuliffe, 1978; Fogell, 2010). Purposeful and accidental releases beyond its native range in North America have caused major changes to ecosystems worldwide where they now occur (Moyle, 1973; Kats and Ferrer, 2003; see Kraus, 2009). Some effects of bullfrog introductions include consumption of other vertebrate species (Bury and Whelan, 1984; Krupa, 2002), interspecific competition (Kiesecker et al., 2001), and increased occurrence and transmission of the amphibian chytrid fungus (Batrachochytrium dendrobatidis; Lawler et al., 1999; Bai et al., 2010). For example, Northern Leopard Frogs (Lithobates pipiens) appear to have been dramatically impacted by bullfrogs in western parts of North America (Hammerson, 1982; Johnson et al., 2011). Furthermore, in Ontario, Canada, Hecnar and McCloskey (1997) demonstrated that when bullfrogs were eradicated from an area, populations of other amphibians increased, in part, due to predator release. Bullfrogs have been included in the list of the 100 worst invasive species worldwide (Lowe et al., 2000; Crayon, 2009). 
Understanding the potential role of non-native bullfrogs in the decline of native amphibians is important because native amphibians are often vital components in both terrestrial and aquatic ecosystems (Whiles et al., 2006).

In addition, many amphibian species are experiencing declines due to the emergence of the amphibian chytrid fungus Batrachochytrium dendrobatidis (Berger et al., 1998; Daszak et al., 1999; Skerratt et al., 2007). The amphibian chytrid fungus causes hyperkeratosis, a skin infection that creates erosions and, sometimes, ulcerations on the epidermis (Berger et al., 1998; Bosch et al., 2001). Death may ensue due to osmotic imbalance which leads to heart dysfunction (Voyles et al., 2009). Although many amphibians appear susceptible to the disease, bullfrogs normally do not show symptoms (Daszak et al., 2004) and are considered carriers, likely having a role in sustaining the fungus at sites and in transmission of the fungus to other species (Hanselmann et al., 2004; Garner et al., 2006). However, Gervasi et al. (2013) recently suggested that bullfrogs also can succumb to chytridiomycosis depending on the strain of the amphibian chytrid fungus that they are exposed to and the number of zoospores that are present at this exposure.

To date, little is known about the distribution or ecological effects of bullfrogs at the Valentine National Wildlife Refuge, Nebraska, USA (Corn et al., 1995; hereafter, the Refuge). In a herpetofaunal survey at the Refuge in 1991-1992, Corn et al. (1995) documented bullfrogs only at Hackberry Lake. In a comprehensive resurvey of the Refuge in 2012, we provide an update on the distribution of bullfrogs, in addition to investigating their diet and prevalence of the amphibian chytrid fungus in the species. Because bullfrogs are known to consume numerous prey species, including other species of frogs (Bury and Whelan, 1984), we were interested in examining whether bullfrogs directly affect native amphibians via predation at the Refuge, specifically the Northern Leopard Frog. Moreover, the amphibian chytrid fungus has recently been documented along the Platte River in south-central Nebraska, but no documentation exists in north-central parts of the state (Harner et al., 2011; Harner et al., 2013). Because the Refuge is located in the Sandhill Region of Nebraska, a rather pristine area of the state with little urban or suburban land use, we predicted that the fungus would be absent or have low prevalence in amphibian populations (Johnson et al., 2011).

\section{MATERIALS AND METHODS}

We surveyed for bullfrogs in June and July 2012 throughout the Valentine National Wildlife Refuge, Cherry County, in north-central Nebraska, USA, to determine their distribution. Survey sites included all major wetlands and lakes at the Refuge. We recorded visual sightings for bullfrogs with most observations occurring during the daytime. To better understand the historical abundance and distribution of bullfrogs on the Refuge, we interviewed Len McDaniel, a long-time biologist in the region and Wildlife Biologist at the Refuge from 19772001.

To sample for presence of the amphibian chytrid fungus, we captured bullfrogs on 2 June, 29 June, 24 July, and 26 July 2012. Bullfrogs $(n=51)$ were captured by hand at night, and we used a swabbing method to collect skin samples; 21 individuals were sampled from Pelican Lake, 8 from Duck Lake, 8 from West Long Lake, 7 from Watts Lake, 4 from Hackberry Lake, and 3 from Dewey Lake. Each bullfrog was swabbed with a nylon swab 20 times each on the belly, thighs, and feet (Fisherfinest Transport Swabs, Fisher Scientific Inc., Pittsburgh, PA, USA). Swabs were air dried and then stored on ice or in freezers until placed on dry ice and sent to the laboratory for testing. Contamination between frogs was limited by wearing vinyl gloves and changing them for each individual handled. We released most bullfrogs at sites of capture.

In the laboratory, we extracted DNA from the swab samples using Qiagen DNEasy spin columns and then ran a Taqman based fast qPCR (Quantitative Polymerase Chain Reaction) assay to determine the presence or absence of the chytrid fungus (Kerby et al., 2013). Samples were run in triplicate with both negative and positive controls per plate. Samples were designated as positive for the amphibian chytrid fungus if a minimum of $2 / 3$ samples in each triplicate were positive. Samples with only a single positive result were rerun and determined to be positive if at least one of the subsequent triplicate was positive.

After swabbing bullfrogs in late July, 15 bullfrogs were collected for dietary analyses from Pelican and Dewey lakes. Larger bullfrogs ( $\geq 100 \mathrm{~mm}$ snout-vent length) were chosen to facilitate the potential for finding recently metamorphosed frogs in their stomach. Bullfrogs were placed in a container filled with a low dose (approximately $1 \%$ ) Tricaine-S (Western Chemical Inc., Ferndale, WA, USA) in water for anesthetization, then, they were euthanized by exposing them to a lethal concentration of Tricaine-S. Twelve additional stomach samples were obtained from frogs captured by fisherman on Dewey Lake at the Refuge in August 2012. Frogs were placed in individually labeled water-proof bags and frozen for stomach analyses in the laboratory. We identified prey to lowest identifiable taxonomic determination and reported number of prey items in stomachs, number of frogs that consumed prey items, and percentage of frog stomachs with specific prey items.

\section{RESULTS}

Bullfrogs were observed in 33 of the 35 major lakes and marsh complexes throughout the refuge (Appendix 1 ), including all nine public fishing lakes. We did not observe bullfrogs inhabiting the two lakes farthest east on the Refuge (i.e., East Long and Crooked lakes) where human access is limited, although suitable frog habitat was available. Lakes with bullfrogs, and the two without bullfrogs, had emergent vegetation around their edges including bulrushes (Scirpus spp.), cattails (Typha spp.), and common reed (Phragmites spp.). We also documented bullfrogs in stock tanks with vegetation. At most lakes with bullfrogs, we failed to detect Northern Leopard Frogs during our brief surveys, but we observed both frog species on Pelican and Marsh lakes. Once we observed at least one bullfrog at a lake, we did not further search for leopard frogs, hence leopard frogs are likely to occur at more lakes throughout the refuge albeit in lower densities or are less obvious.

Len McDaniel reports having observed bullfrogs on the Refuge in 1963 and 1977-2001, with most bullfrogs west of U.S. Highway 83 in Watts, Hackberry, Dewey, West Long, Duck, Rice, and Pelican lakes, as well as, Sawyer Meadow. He observed occasional sightings on Marsh Lakes east of U.S. Highway 83.

Stomach analyses demonstrated that amphibians were among the wide variety of organisms consumed by bullfrogs (Table 1). Three bullfrogs had empty stomachs, four had an unidentifiable frog in their stomach, and one 
Table 1. Stomach contents of 27 American Bullfrogs (Lithobates catesbeianus) from the Valentine National Wildlife Refuge in Cherry County, Nebraska, USA, July and August 2012. For higher taxonomic categories, summation of lower taxa within those categories is reported in parentheses.

\begin{tabular}{|c|c|c|c|}
\hline Category & $\begin{array}{l}\text { No. food } \\
\text { items }\end{array}$ & $\begin{array}{l}\text { No. stomachs } \\
\text { with food } \\
\text { items }\end{array}$ & $\begin{array}{l}\text { Stomachs } \\
\text { with food } \\
\text { items (\%) }\end{array}$ \\
\hline Phylum Arthropoda & $(114)$ & $(21)$ & (78) \\
\hline Class Insecta & $(98)$ & (20) & $(74)$ \\
\hline Order Coleoptera & $(47)$ & (16) & (59) \\
\hline Unidentified Coleoptera & 10 & 6 & 22 \\
\hline Family Cicindelidae (Cicindela punctulata) & 1 & 1 & 4 \\
\hline Family Dytiscidae & 2 & 1 & 4 \\
\hline Family Silphidae (Necrophila americana) & 6 & 5 & 19 \\
\hline Family Staphylinidae & 4 & 2 & 7 \\
\hline Family Curculionidae & 2 & 2 & 7 \\
\hline Family Omophronidae & 5 & 1 & 4 \\
\hline Family Carabidae (Unidentified) & 14 & 8 & 30 \\
\hline Genus Elaphras & 3 & 3 & 11 \\
\hline Order Odonata & (9) & $(8)$ & $(30)$ \\
\hline Unidentified Odonota & 2 & 2 & 7 \\
\hline Family Coenagrionidae & 1 & 1 & 4 \\
\hline Suborder Anisoptera & 1 & 1 & 4 \\
\hline Family Libellulidae & 5 & 4 & 15 \\
\hline Order Hymenoptera & (9) & $(8)$ & $(30)$ \\
\hline Unidentified Hymenoptera & 3 & 3 & 11 \\
\hline Family Vespidae & 4 & 4 & 15 \\
\hline Family Formicidae & 1 & 1 & 4 \\
\hline Family Pompilidae & 1 & 1 & 4 \\
\hline Order Diptera & $(13)$ & (7) & $(26)$ \\
\hline Unidentified Diptera & 8 & 4 & 15 \\
\hline Family Tipulidae & 3 & 3 & 11 \\
\hline Suborder Brachycera & 2 & 1 & 4 \\
\hline Order Ephemeroptera & 1 & 1 & 4 \\
\hline Order Lepidoptera & 2 & 2 & 7 \\
\hline Order Collembola & 3 & 2 & 7 \\
\hline \multicolumn{4}{|l|}{ Order Hemiptera } \\
\hline Family Belostomatidae & 8 & 4 & 15 \\
\hline Order Orthoptera & (6) & (4) & $(15)$ \\
\hline Family Acrididae & 1 & 1 & 4 \\
\hline Family Gryllidae & 2 & 2 & 7 \\
\hline Family Gryllotalpidae & 3 & 1 & 4 \\
\hline Class Arachnida & $(6)$ & (4) & $(15)$ \\
\hline Order Araneae & 5 & 3 & 11 \\
\hline Order Opiliones (Suborder Palpatores) & 1 & 1 & 4 \\
\hline Class Malacostraca & $(10)$ & (7) & $(26)$ \\
\hline Order Amphipoda & 3 & 1 & 4 \\
\hline Order Decapoda & 7 & 6 & 22 \\
\hline Phylum Mollusca & (9) & (5) & (19) \\
\hline Class Gastropoda (Unidentified) & 8 & 4 & 15 \\
\hline Family Planorbidae & 1 & 1 & 4 \\
\hline Phylum Cordata & (7) & (6) & $(22)$ \\
\hline Class Amphibia & (6) & (5) & (19) \\
\hline \multicolumn{4}{|l|}{ Order Anura } \\
\hline \multicolumn{4}{|l|}{ Family Ranidae } \\
\hline Unidentified Ranidae & 4 & 4 & 15 \\
\hline Lithobates catesbeianus & 2 & 1 & 4 \\
\hline Class Reptilia & (1) & (1) & (4) \\
\hline \multicolumn{4}{|l|}{ Order Testudines } \\
\hline Family Emydidae (Emydoidea blandingii) & 1 & 1 & 4 \\
\hline Phylum Nematode/Nematomorpha & (4) & (1) & (4) \\
\hline
\end{tabular}


had two smaller bullfrogs in its stomach. In total, 134 total organisms from four different phyla were consumed by bullfrogs (Table 1), with chordates (i.e., bullfrogs, unknown frogs, and a Blanding's Turtle, Emydoidea blandingii) representing $5.2 \%$ of the diet and insects representing $73.1 \%$. We detected at least 9 orders and 17 families of insects in bullfrog diets (Table 1 ). We observed that $22 \%$ of individuals contained a prey item in the phylum Chordata (Table 1). Of 51 bullfrogs sampled for the amphibian chytrid fungus, $16(31.4 \%)$ tested positive for the fungus. In early June, 14 of $19(73.7 \%)$ bullfrogs were positive for chytrid and from late June to late July, 2 of $32(6.3 \%)$ bullfrogs tested positive.

\section{DISCUSSION}

We observed bullfrogs to be almost ubiquitous across the Refuge in major lakes and marsh complexes. Although there is only one previously published record of bullfrogs at the Refuge, occurring at Hackberry Lake (Corn et al., 1995), our conversations with a long-time resident and biologist of the region confirmed that the species had been observed at additional locations for decades. Countless bullfrogs were released throughout the state prior to and during the early 1940 s by the Nebraska Game and Parks Commission (Hudson, 1942). We suspect that the "fishing lakes" on the Refuge likely were the original site of bullfrog stockings either by accident or intentionally. Considering bullfrogs are known to colonize new water sources $\leq 1 \mathrm{~km}$ by traveling over land (Snow and Witmer, 2010), and during wet years water flows between many of the Refuge lakes and wetlands (M. Nenneman, personal observation), the widespread occurrence of the species is not surprising. We suspect it is a matter of time before bullfrogs will be observed at East Long and Crooked lakes on eastern parts of the Refuge. Therefore, given the amount of time bullfrogs have occurred on the Refuge, connectivity of waterways, and relatively short distances between more isolated lakes, bullfrogs have demonstrated their ability to be invasive at this wildlife refuge in north-central Nebraska.

Many studies have reported that bullfrogs consume a variety of organisms (e.g., Bury and Whelan, 1984; Kru$\mathrm{pa}, 2002)$. At the Refuge, insects were the most frequent prey item consumed by bullfrogs, which is similar to the findings of other studies where insects and crayfish were commonly consumed by bullfrogs (see Bury and Whelan, 1984). Many insects consumed by bullfrogs at the Refuge are associated with wetland, lake, and marshy habitats (Arnett, 1985). Small turtles occasionally are reported in the diet of bullfrogs (Bury and Whelan, 1984). Consumption of a Blanding's Turtle on the Refuge represents a Tier 1 species of concern in Nebraska (Schneider et al., 2011). We documented consumption of a total of six frogs in stomachs, two of which were bullfrogs, but we were unable to identify the remaining four frogs to species. Frogs commonly are consumed by bullfrogs (e.g., Bury and Whelan, 1984). We suspect that with more sampling, bullfrogs would be shown to directly consume native amphibians on the Refuge. The lack of many lakes and marshes with an abundance of both bullfrogs and northern leopard frogs suggests an interaction may be occurring between them. Although our preliminary information cannot ascertain a mechanism of interaction, the potential exists for both predation by bullfrogs and presence of bullfrogs resulting in the sustained presence of the amphibian chytrid fungus, increasing the likelihood of interspecific transmission of the pathogen.
Our observations of the presence of the amphibian chytrid in bullfrogs at the Refuge represent the first detection of the amphibian chytrid fungus in northern Nebraska and the third published locality in the state (Harner et al., 2011; Harner et al., 2013). The Refuge is situated on a rather pristine location in the Sandhill Region of $\mathrm{Ne}$ braska with minimal human disturbance, thus we expected that amphibian chytrid may not be present or could occur at a low prevalence (Johnson et al., 2011). Fishing is allowed in nine of the lakes, which may be linked to its presence because human activities are strongly suspected to aid the spread of the chytrid fungus (Schloegel et al., 2009). Sampling of bullfrogs museum/archival specimens in North America (Ouellet et al., 2005) and other countries (Weldon et al., 2004) has demonstrated that the introduction of this fungus may have occurred decades ago; the earliest finding in North America to date is from Saint-Pierre-de-Wakefield, Quebec in 1961 (Oullet et al., 2005). Thus, the fungus might have always been present from early human activities in the area such as the initial bullfrog stockings throughout Nebraska. Chytrid prevalence at the Refuge was $31.4 \%$, similar to rates observed in south-central Nebraska (Harner et al., 2011; Harner et al., 2013). We predict that amphibian chytrid fungus likely occurs throughout Nebraska where bullfrogs are present.

Our data appear to support the climate-chytrid paradox (Pounds et al., 2006) at the Refuge. For most pathogens, as temperatures rise, disease outbreaks are triggered and many become more lethal or spread more rapidly; however, amphibian chytrid fungus is more pathogenic at lower temperatures (Berger et al., 2004). Our results suggested a pattern between prevalence rates of amphibian chytrid and temperature, with higher rates of chytrid documented during a cooler period of time. In early June, $73.7 \%$ of samples tested positive for chytrid, whereas from late June to late July, only $6.3 \%$ were positive. Average high temperature for the 30 days prior to the early June sampling date was $23.2^{\circ} \mathrm{C}$, whereas average high temperature 30 days prior to 24 July was $37.0^{\circ} \mathrm{C}$ (temperatures reported at Valentine, Nebraska; wunderground.com). This study represents the third example of this relationship in Nebraska, comparing early sampling dates to those samples collected later in the season (K. Geluso, unpublished data; Harner et al., 2011; Harner et al., 2013). For methodological purposes, additional sampling for amphibian chytrid should be conducted during cooler seasons and not during the hottest months of the year to promote its detection in amphibian populations.

Although our study was not designed specifically to assess the effects of bullfrogs on Northern Leopard Frogs at the Refuge, we hypothesize that a negative interaction is occurring due to the paucity of Northern Leopard Frogs in our surveys. During nighttime sampling, we observed hundreds of bullfrogs whereas we only observed a few (< 5) Northern Leopard Frogs. Bullfrogs are likely affecting native amphibian species via both interspecific interactions and disease transmission. Although bullfrogs may be difficult to eradicate from the Refuge (see Snow and Witmer, 2010), especially given their current abundance and distribution, population control measures may benefit native species. Bullfrogs are currently a game species in Nebraska, with seasonal, size, and bag limits in place to prevent overharvesting (McAuliffe, 1978). In other areas with high bullfrog harvest rates, bullfrog numbers have decreased (Hudson, 1942; McAuliffe, 1978). Therefore, if regulations on bullfrog harvest were lessened or 
eliminated in Nebraska, their abundance may decrease which could potentially benefit native amphibian and other vertebrate populations at the Refuge, as well as, across the state. However, incidental harvest of native frogs is a concern; hence elevated bullfrog harvest may warrant monitoring to assess effects on both native species and this invasive species. We propose that bullfrogs should be delisted as a game species across much of Nebraska where there were no native populations.

\section{ACKNOWLEDGMENTS}

We thank Mark Lindvall (US Fish and Wildlife Service) for allowing us to conduct this study at the Valentine National Wildlife. We thank the Undergraduate Research Fellows program and Undergraduate Research Council at the University of Nebraska at Kearney (UNK) for funding. We thank Justin Vogel for assistance in the field, Aric Buerer and Brittney Adams for assistance in frog dissections, and two anonymous reviewers for detailed comments that improved our manuscript. This study was approved by the Institutional Care and Use Committee at UNK.

\section{LITERATURE CITED}

Arnett, R.H., Jr. 1985. American insects: A handbook of the insects of America north of Mexico. Van Nostrand Reinhold Company Inc., New York, 850 pp.

Bai, C., T.W.J. Garner, and Y. Li. 2010. First evidence of Batrachochytrium dendrobatidis in China: Discovery of chytridiomycosis in introduced American bullfrogs and native amphibians in the Yunnan Province, China. EcoHealth 7:127-134.

Berger, L., R. Speare, P. Daszak, D.E Green, A.A. Cunningham, C.L. Goggin, R. Slocombe, M.A. Ragan, A.D. Hyatt, K.R. McDonald, H.B. Hines, K.R. Lips, G. Marantelli, and H. Parkes. 1998. Chytridiomycosis causes amphibian mortality associated with population declines in the rain forests of Australia and Central America. Proceedings of the National Academy of Sciences, USA 95:9031-9036.

Berger, L., R. Speare, H.B., Hines, G. Marantelli, A.D. Hyatt, K.R. McDonald, L.F. Skerratt, V. Olsen, J.M. Clarke, G. Gillespie, M. Mahony, N. Sheppard, C. Williams, and M.J. Tyler. 2004. Effects of season and temperature on mortality in amphibians due to chytridiomycosis. Australian Veterinary Journal 82:434439.

Bosch, J., I. Martinez-Solano, and M. Garcia-Paris. 2001. Evidence of a chytrid fungus infection involved in the decline of the common midwife toad (Alytes obstetricans) in protected areas of central Spain. Biological Conservation 97:331-337.

Bury, R.B., and J.A. Whelan. 1984. Ecology and management of the bullfrog. United States Department of the Interior, Fish and Wildlife Service Resource Publications 155:1-26.

Corn, P.S., M.L. Jennings, and R.B. Bury. 1995. Amphibians and reptiles. pp. 32-59 in A biological survey of Fort Niobrara and Valentine National Wildlife Refuges (M.A. Bogan, Ed.). National Biological Service, Midcontinent Ecological Science Center, Fort Collins, CO.

Crayon, J.J. 2009. Global Invasive Species Database: Lithobates catesbeianus. http://www.issg.org/ database/species/ecology.asp? $\mathrm{si}=80 \& \mathrm{fr}=1 \& \mathrm{sts}=$ \&lang $=\mathrm{EN}$

Daszak, P., L. Berger, A.A. Cunningham, A.D. Hyatt, D.E. Green, and R. Speare. 1999. Emerging infectious diseases and amphibian population declines. Emerging Infectious Diseases 5:735-748.

Daszak, P., A. Strieby, A.A. Cunningham, J.E. Longcore, C.C. Brown, and D. Porter. 2004. Experimental evidence that the bullfrog (Rana catesbeiana) is a potential carrier of chytridiomycosis, an emerging fungal disease of amphibians. Herpetological Journal 14:201-207.

Ficetola, G.F., W. Thuiller, and C. Miaud. 2007. Prediction and validation of the potential global distribution of a problematic alien invasive species-the American bullfrog. Diversity and Distributions 13:476-485.

Fogell, D.D. 2010. A field guide to the amphibians and reptiles of Nebraska. Institute of Agriculture and Natural Resources, University of Nebraska-Lincoln. $158 \mathrm{pp}$.

Garner, T.W.J., M.W. Perkins, P. Govindarajulu, D. Seglie, S. Walker, A.A. Cunningham, and M.C. Fisher. 2006. The emerging amphibian pathogen Batrachochytrium dendrobatidis globally infects introduced populations of the North American bullfrog, Rana catesbeiana. Biology Letters 2:455-459.

Gervasi, S.S., J. Urbina, J. Hua, T. Chestnut, R.A. Relyea, and A.R. Blaustein. 2013. Experimental evidence for American bullfrogs (Lithobates catesbeianus) susceptibility to chytrid fungus (Batrachochytrium dendrobatidis). EcoHealth DOI: 10.1007/s10393013-0832-8.

Hammerson, G.A. 1982. Bullfrog eliminating leopard frogs in Colorado? Herpetological Review 13:115116.

Hanselmann, R., A. Rodriguez, M. Lampo, L. Fajardo-Ramos, A.A. Aguirre, A.M. Kilpatrick, J.P. Rodriguez, and P. Daszak. 2004. Presence of an emerging pathogen of amphibians in introduced bullfrogs Rana catesbeiana in Venezuela. Biological Conservation 120:115-119.

Harner, M.J., A.J. Nelson, K. Geluso, and D.M. Simon. 2011. Chytrid fungus in American bullfrogs (Lithobates catesbeianus) along the Platte River, Nebraska, USA. Herpetological Review 42:549-551.

Harner, M.J., J.N. Merlino, and G.D. Wright. 2013. Amphibian chytrid fungus in Woodhouse's toads, plains leopard frogs, and American bullfrogs along the Platte River, Nebraska, USA. Herpetological Review 44:459-461.

Hecnar, S.J., and R.T. McCloskey. 1997. Changes in the composition of a ranid frog community following bullfrog extinction. American Midland Naturalist 137:145-150.

Hudson, G.E. 1942. The amphibians and reptiles of Nebraska. Nebraska Conservation Bulletin 24:1-146.

Johnson, P.T.J., V.J. McKenzie, A.C. Peterson, J.L. Kerby, J. Brown, A.R. Blaustein, and T. Jackson. 2011. Regional decline of an iconic amphibian associated with elevation, land-use change, and invasive species. Conservation Biology 25:556-566.

Kats, L.B., and R.P. Ferrer. 2003. Alien predators and amphibian declines: Review of two decades of science and the transition to conservation. Diversity and Distributions 9:99-110.

Kerby, J.L., A. Schieffer, J.R. Brown, and S. Whitfield. 2013. Utilization of fast qPCR techniques to detect the amphibian chytrid fungus: A cheaper and more efficient alternative method. Methods in Ecology and Evolution 4:162-166.

Kiesecker, J.M., A.R. Blaustein, and C.L. Miller. 2001. 
Potential mechanisms underlying the displacement of native red-legged frogs by introduced bullfrogs. Ecology 82:1964-1970.

Kraus, F. 2009. Alien reptiles and amphibians: A scientific compendium and analysis. Springer. 563pp.

Krupa, J.J. 2002. Temporal shift in diet in a population of American bullfrog (Rana catesbeiana) in Carlsbad Caverns National Park. The Southwestern Naturalist 47:461-467.

Lawler, S.P., D. Dritz, T. Strange, and M. Holyoak. 1999. Effects of introduced mosquitofish and bullfrogs on the threatened California red-legged frog. Conservation Biology 13:613-622.

Lowe, S., M. Brown, S. Boudjelas, and M. De Poorter. 2000. 100 of the world's worst invasive alien species. A selection from the global invasive species database. Published by The Invasive Species Specialist Group of the Species Survival Commission of the World Conservation Union. 12 pp. Available at www. issg.org/booklet.pdf.

McAuliffe, J.R. 1978. Biological survey and management of sport-hunted bullfrog populations in Nebraska. Report submitted to the Nebraska Game and Parks Commission, Lincoln, NE. 72 pp.

Moyle, P.B. 1973. Effects of introduced bullfrogs, Rana catesbeiana, on the native frogs of the San Joaquin Valley, California. Copeia 1973:18-22.

Ouellet, M., I. Mikaelian, B.D. Pauli, J. Rodrigue, and D.M. Green. 2005. Historical evidence of widespread chytrid infection in North American amphibian populations. Conservation Biology 19:1431-1440.

Pounds, J.A., M.R. Bustamante, L.A. Coloma, J.A. Consuegra, M.P.L. Fogden, P.N. Foster, E. La Marca, K.L. Masters, A. Merino-Viteri, R. Puschendorf, S.R. Ron, G.A. Sanchez-Azofeifa, C.J. Still, and B.E. Young. 2006. Widespread amphibian extinctions from epidemic disease driven by global warming. Nature
439:161-167.

Schloegel, L.M., A.M. Picco, A.M. Kilpatrick, A.J. Davies, A.D. Hyatt, and P. Daszak. 2009. Magnitude of the US trade in amphibians and presence of Batrachochytrium dendobatidis and ranavirus infection in imported North American bullfrogs (Rana catesbeiana). Biological Conservation 142:1420-1426.

Schneider, R., K. Stoner, G. Steinauer, M. Panella, and M. Humpert. 2011. The Nebraska Natural Legacy Project: State Wildlife Action Plan. $2^{\text {nd }}$ ed. The Nebraska Game and Parks Commission, Lincon, NE. 344 pp.

Skerratt, L., L. Berger, R. Speare, S. Cashins, K. McDonald, A. Phillott, H.B. Hines, and N. Kenyon. 2007. Spread of chytridiomycosis has caused the rapid global decline and extinction of frogs. Eco-Health 4:125-134.

Snow, N.P., and G. Witmer. 2010. American bullfrogs as invasive species: A review of the introduction, subsequent problems, management options, and future directions. Pp. 86-89 In Proceedings of the $24^{\text {th }}$ Vertebrate Pest Conference (R.M. Timm and K.A. Fagerstone, Eds.). University of California, Davis.

Voyles, J., S. Young, L. Berger, C. Campbell, W.F. Voyles, A. Dinudom, D. Cook, R. Webb, R.A. Alford, L.F. Skerratt, and R. Speare. 2009. Pathogenesis of chytridiomycosis, a cause of catastrophic amphibian declines. Science 326:582-585.

Weldon, C., L.H. du Preez, A.D. Hyatt, R. Muller, and R. Speare. 2004. Origin of the amphibian chytrid fungus. Emerging Infectious Diseases 10:2100-2105.

Whiles, M.R., K.R. Lips, C.M. Pringle, S.S. Kilham, R.J. Bixby, R. Brenes, S. Connelly, J.C. Colon-Gaud, M. Hunte-Brown, A.D. Huryn, C. Montgomery, and S. Peterson. 2006. The effects of amphibian population declines on the structure and function of Neotropical stream ecosystems. Frontiers in Ecology and the Environment 4:27-34.

APPENDIX 1. Localities of lakes on the Valentine National Wildlife Refuge, Cherry County, Nebraska, USA, where bullfrogs were observed and locations without bullfrogs in 2012. Latitudes and longitudes were determined via Google.earth.com

LAKES WITH BULLFROGS: 1. Baker Lake $\left(42.4966^{\circ} \mathrm{N}, 100.6212^{\circ} \mathrm{W}\right) ; 2$. Calf Camp Marsh $\left(42.5263^{\circ} \mathrm{N}, 100.5587^{\circ} \mathrm{W}\right) ; 3$. Campbell Lake $\left(42.4687^{\circ} \mathrm{N}, 100.5793^{\circ} \mathrm{W}\right) ; 4$. Center Lake $\left(42.4792^{\circ} \mathrm{N}, 100.4858^{\circ} \mathrm{W}\right) ; 5$. Clear Lake $\left(42.5577^{\circ} \mathrm{N}, 100.6171^{\circ} \mathrm{W}\right)$; 6. Coleman Lake $\left(42.4611^{\circ} \mathrm{N}, 100.6443^{\circ} \mathrm{W}\right) ; 7$. Cow Lake $\left(42.4431^{\circ} \mathrm{N}, 100.5350^{\circ} \mathrm{W}\right) ; 8$. Dad's Lake $\left(42.4983^{\circ} \mathrm{N}, 100.6624^{\circ} \mathrm{W}\right)$; 9. Devil's Punch Bowl $\left(42.4900^{\circ} \mathrm{N}, 100.7051^{\circ} \mathrm{W}\right) ; 10$. Dew Lake $\left(42.4488^{\circ} \mathrm{N}, 100.3506^{\circ} \mathrm{W}\right) ; 11$. Dewey Lake $\left(42.5450^{\circ} \mathrm{N}\right.$, 100.6288 $\mathrm{W})$; 12. Duck Lake $\left(42.5432^{\circ} \mathrm{N}, 100.7262^{\circ} \mathrm{W}\right) ; 13$. East Sweetwater Lake $\left(42.4492^{\circ} \mathrm{N}, 100.5163^{\circ} \mathrm{W}\right)$; 14 . East Twin Lake $\left(42.5048^{\circ} \mathrm{N}, 100.5311^{\circ} \mathrm{W}\right) ; 15$. Hackberry Lake $\left(42.5627^{\circ} \mathrm{N}, 100.6813^{\circ} \mathrm{W}\right) ; 16$. Homestead Lake $\left(42.4646^{\circ} \mathrm{N}, 100.5655^{\circ} \mathrm{W}\right) ; 17$. Lee Lake $\left(42.4625^{\circ} \mathrm{N}, 100.4987^{\circ} \mathrm{W}\right) ; 18$. Little Hay Lake $\left(42.5383^{\circ} \mathrm{N}, 100.5562^{\circ} \mathrm{W}\right) ; 19$. Lost Lake $\left(42.4891^{\circ} \mathrm{N}, 100.5936^{\circ} \mathrm{W}\right) ; 20$. Marsh Lakes $\left(42.5182^{\circ} \mathrm{N}, 100.5020^{\circ} \mathrm{W}\right) ; 21$. McKeel Lake $\left(42.5327^{\circ} \mathrm{N}, 100.5917^{\circ} \mathrm{W}\right) ; 22$. Mule Lake $\left(42.4862^{\circ} \mathrm{N}, 100.6759^{\circ} \mathrm{W}\right)$; 23. Pelican Lake $\left(42.5268^{\circ} \mathrm{N}, 100.6721^{\circ} \mathrm{W}\right)$; 24 . Pony Lake $\left(42.4874^{\circ} \mathrm{N}, 100.5125^{\circ} \mathrm{W}\right) ; 25$. Rice Lake $\left(42.5543^{\circ} \mathrm{N}, 100.7227^{\circ} \mathrm{W}\right)$; 26. School Lake $\left(42.5270^{\circ} \mathrm{N}, 100.6103^{\circ} \mathrm{W}\right) ; 27$. Tom's Lake $\left(42.4784^{\circ} \mathrm{N}, 100.5352^{\circ} \mathrm{W}\right) ; 28$. Twenty-one Lake $\left(42.4712^{\circ} \mathrm{N}\right.$, $\left.100.4599^{\circ} \mathrm{W}\right) ; 29$. Watts Lake $\left(42.5778^{\circ} \mathrm{N}, 100.6887^{\circ} \mathrm{W}\right) ; 30$. West Long Lake $\left(42.5278^{\circ} \mathrm{N}, 100.7221^{\circ} \mathrm{W}\right)$; 31 . West Twin Lake $\left(42.5086^{\circ} \mathrm{N}, 100.5623^{\circ} \mathrm{W}\right)$; 32 . Whitewater Lake $\left(42.5338^{\circ} \mathrm{N}, 100.6484^{\circ} \mathrm{W}\right)$; 33. Willow Lake $\left(42.5521^{\circ} \mathrm{N}, 100.5865^{\circ} \mathrm{W}\right)$.

LAKES WITHOUT BULLFROGS: 1 . Crooked Lake $\left(42.4429^{\circ} \mathrm{N}, 100.3877^{\circ} \mathrm{W}\right) ; 2$. East Long Lake $\left(42.4244^{\circ} \mathrm{N}\right.$, $\left.100.4003^{\circ} \mathrm{W}\right)$. 